\title{
Insects: novel source of lipids for a fan of applications
}

\author{
Nathalie Berezina* \\ Ynsect, 1 rue Pierre-Fontaine, 91058 Évry, France
}

Received 15 February 2017 - Accepted 4 June 2017

\begin{abstract}
The insect industry is rapidly emerging these last years. If the main product of this industry is the protein meal, used mainly for feed and food applications, only a few work has been done on the main coproduct of this industry, the insects' oils. However, these oils deserve all our interest, as they present very interesting characteristics and particularity depending on the origin and feed source of the producing insect. In this short review, we are discussing different aspects of these products biosynthesis, composition and potential applications.
\end{abstract}

Keywords: biosynthesis / oils / fats / biodiesel / body care / biomaterials

Résumé - Insectes : une nouvelle source de lipides pour un éventail d'applications. L'industrie des insectes se développe rapidement ces dernières années. Si le produit principal de cette industrie reste la farine protéique, essentiellement utilisée à des fins de nutrition humaine et animale, relativement peu de travaux concernent le coproduit principal de cette industrie, à savoir les huiles. Cependant ces huiles méritent toute notre attention tant leurs propriétés et caractéristiques sont intéressantes et diverses selon l'origine et le régime alimentaire de l'insecte dont elles sont issues. Dans ce court article nous nous sommes attelés à présenter les différents aspects de la biosynthèse, composition et potentielles utilisations de ces produits.

Mots clés : biosynthèse / huiles / graisses / biodiesel / soin du corps / biomatériaux

\section{Introduction}

Since the FAO has warned about the interest of cultivation of insects to supply the growing population with proteins (Van Huis et al., 2013), lots of scientists and companies have launched research work on this field. It is, however, worthwhile to notice, that besides the main-stream product, proteins, insects are also concomitantly producing lipids and chitin. Lipids being much more abundant, 30-50\% of dry mass, comparing to chitin, $2-5 \%$ of dry mass of insects, they represent the major co-product of insect protein meal industry (excluding feces, which in some point may even be the major product, as they contain much less water than the insects themselves).

Knowing that, it becomes extremely interesting to understand what this lipids can be used for. To answer this question, it is, however, extremely important to understand how those molecules are biosynthesized by the insect, are those pathways similar or different to those of plants or other animals. It will then help to understand the relationship between the feed source and the intimate composition of fatty

\footnotetext{
* Corresponding author: nbe@ynsect.com
}

acids composing these lipids. Then different valorization routes of these products can be considered.

In this short review article we will try to answer several among the above mentioned questions, i.e. the biosynthesis of the insects' lipids, their composition, the possible applications comparing to those already elaborated for plants and algae, for example.

\section{Biosynthesis}

To understand the way the lipids are synthesized within living organisms several studies were conducted. The first to make a hypothesis of "head to tail" linking of acetic acid units was J.N. Collie in 1907 (Morgan, 2010), this hypothesis was further confirmed by A. Birch through the ${ }^{14} \mathrm{C}$ label experiment (Morgan, 2010).

From the chemical point of view, this "head to tail" linking formally corresponds to the Claisen's condensation (Fig. 1), a reaction which requires harsh experimental condensations and the presence of a strong base, such as NaOEt.

A legitimate question would be, how the living organisms can afford such harsh conditions for the realization of this vital reaction? The answer is rather simple, they are not performing exactly this reaction, and actually they are not directly 
<smiles>[R]CC(=O)O[18O]C(=O)C[R]</smiles>

$\underset{\mathrm{NaOEt}}{\stackrel{\text { strong base }}{\longrightarrow}}$

$$
K_{a}=3 \times 10^{-25}
$$

acetate
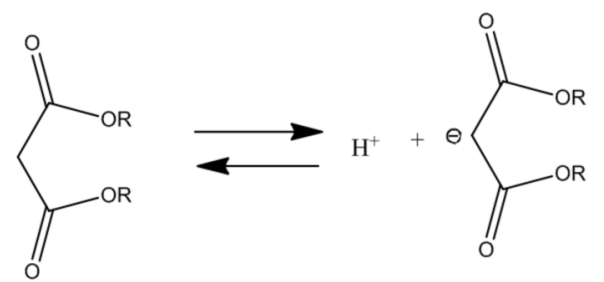

$$
K_{a}=1 \times 10^{-13}
$$

malonate

Fig. 2. Comparison of the production of acetate and malonate ions.

condensing the units of acetic but of malonic acid (Fig. 2). This switch allows the $10^{12}$ energy gain for the extraction of hydrogen for the anion formation and explains how the living organisms can afford this biosynthesis to take place (Morgan, 2010).

The next step would be the understanding of the origin of the malonic acid within those organisms. Actually it results from a rather complex reaction chain (Fig. 3) starting with $\mathrm{CO}_{2}$, water and ATP and where the biotin enzyme plays a key catalytic role (Morgan, 2010). The following step of hydrogen extraction is catalyzed by acyl career protein (ACP) to obtain malonate, the proper condensation is then achieved through the action of $\beta$-keto-synthase (KS) and the whole process requires the action of not less than five different enzymes (Fig. 4).

Interestingly, these enzymes are grouped within the socalled type I fatty acid synthase, which includes two more enzymes, namely thioesterase (TE) and malonyl-acetyl transferase (MAT), and forms a double system allowing thus a simultaneous production of two molecules of fatty acids (Fig. 5). The production of the even carbon number fatty acids results from the primary reaction with acetic acid, the odd carbon number fatty acids being obtained from primarily propionyl units.

However, the above described process leads to saturated fatty acids, then the question of unsaturation has to be addressed. Actually, the unsaturation is mediated by the desaturase $\Delta 9$, a metalloenzyme, which action has been recently proven to be present within insects' biosynthetic pathways (Morgan, 2010). This enzyme allows the withdrawal of two hydrogen atoms through the mediation of iron at different oxidation degrees and the concomitant liberation of one water molecule, thus catalyzing the transformation of unsaturated fatty acids (UFA), e.g. stearic acid C18:0, to polyunsaturated fatty acids (PUFA), e.g. linolenic acid C18:3 (Fig. 6).

The whole biosynthetic pathway of unsaturated fatty acids, from the "head to tail" condensation to the desaturation has been thus elucidated.

\section{Composition}

One of the issues when speaking about the lipids produced by the insects is the generalization of the insects. Indeed, insects being the most biodiverse eukariota worldwide, obviously the composition and the proportion of their inner lipids is very different (Kerkut et Gilbert, 1985). Except for the Hemiptera, where a variety of the major chain length was observed between C14 (Kerkut et Gilbert, 1985) and C18 (Mariod, 2005) with also an important proportion of C16, up to $30 \%$ in Aspongubus vidiatus (melon bug) (Mariod, 2005); the major chain length remains the $\mathrm{C} 18$ for the other studied species. However, major differences can be found between Lepidoptera with up to $22 \%$ of PUFA, C18:3, and Hymenoptera and Dictyoptera with up to $46 \%$ and $42 \%$, respectively, of monosaturated fatty acid, 18:1 (Tab. 1).

Further on, when looking on the relationship between the insect behavior and their fat composition, we can notice that flying insects, such as Lepidoptera or Diptera, requiring more energy usually possess a higher proportion of lipids, up to $40 \%$ of total dry biomass; when the jumping Orthoptera, requiring more muscle are richer in proteins; the Coleoptera being generally better equilibrated between proteins and lipids, $55 \%$ and $34 \%$ of total dry biomass, respectively (Berezina et al., 2016a, 2016b, 2016c; Caruso et al., 2014).

\section{Applications}

Due to their high versatility and rich composition, different applications can be foreseen for oils extracted from the insects. Here, we are mainly detailing some of the most promising such as food and feed applications, energy, surfactants and materials applications of these lipids.

\subsection{Food and feed}

When comparing the fatty acids' composition of two among the most promising insects for the industrial utilization, such as Tenebrio molitor and Hermetia illucnes, we can see that the total amount of UFA is rather close to the one noticed 


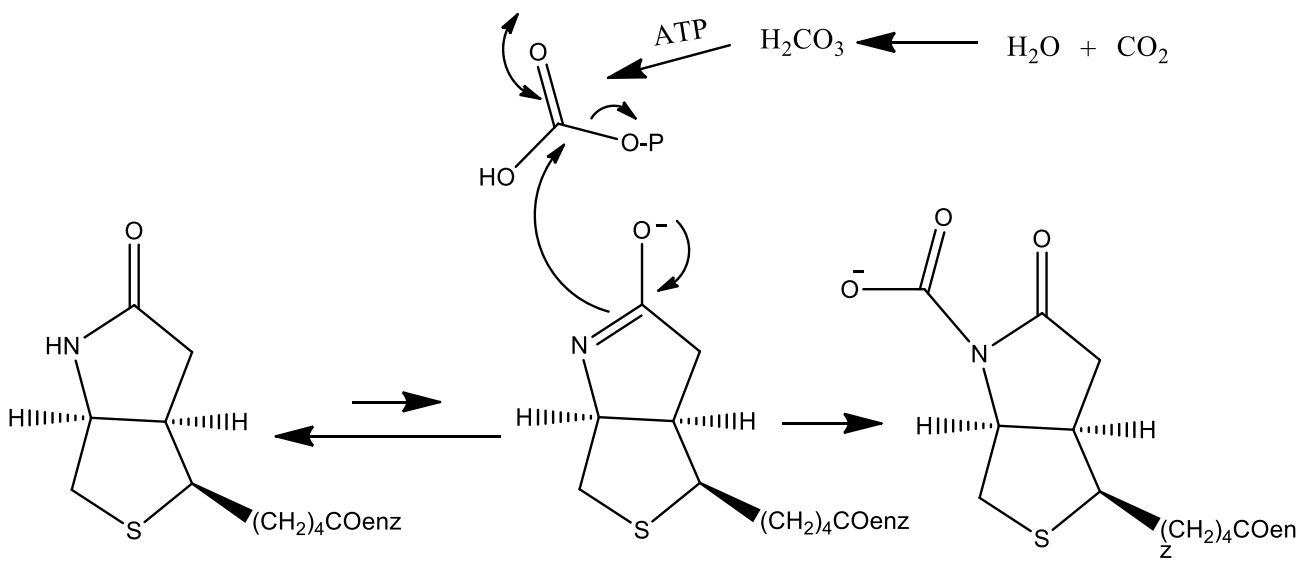

biotin-enzyme

$\mathrm{N}$-carboxybiotin

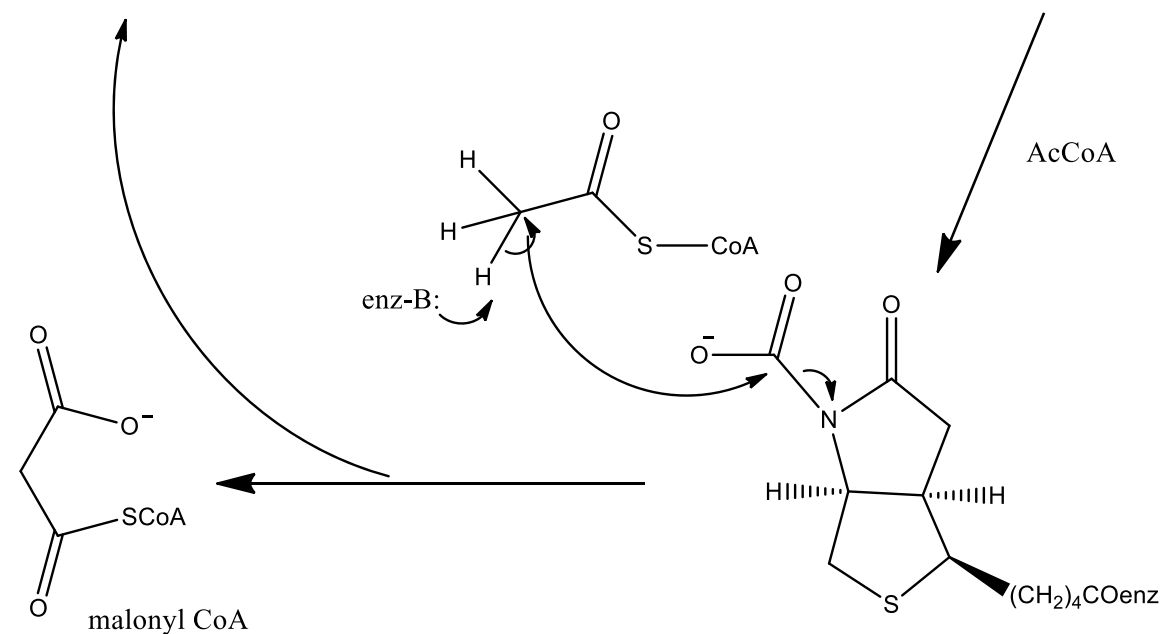

Fig. 3. Biosynthetic pathway for malonyl CoA.

within olive, or soya oils; whereas the proportion of PUFA makes the T. molitor oil suitable for the replacement of either olive, peanut or canola oils (Tab. 2).

However, one should notice, that even if the composition of these insect oils is very similar to the one of some plant oil, to introduce them to the food market, at least in Europe, the Novel Food requirements should be met for the official authorization of these substances to gain human nutrition market; whereas the feed market is fully accessible for the oils from insects and thanks to their composition should be reached very soon. Especially as the overall physicochemical properties and oxidative stability have shown a superior quality with no requirement for further refining, at least in case of $T$. molitor (Jeon et al., 2016).

\subsection{Energy}

After a huge infatuation for the field of biofuels, their production and utilization were submitted to some doubts in the recent years. However, this is one of the aspects of the potential utilization of oils coming from insects which can be considered.
When comparing the advantages and drawbacks of different sources of biodiesel (Tab. 3), we can notice that comparing to the plant sources, the insect source is much less time consuming, and comparing to the algal source, the insects are much less space consuming. Even if the insects are growing slower than the algae and their composition can be less abundant in oil than that of some plants, we need to keep in mind that the oil production of insects is an actual coproduction and they are not reared for that purpose.

Also, the quality of the obtained biodiesel was studied (Zheng et al., 2013). It was thus found that the cetane number, the main intrinsic characteristic of the biofuel, was compliant with the requirements of the European norm EN 14214 and, being 53 for $H$. illucens and even as high as 58 for T. molitor, was found to be much higher than what was observed for the canola oil, 43 (Tab. 4).

\subsection{Soap and other surfactants}

The production of soaps and other surfactants was originally based on the plant fatty acids. Indeed, a surfactant 


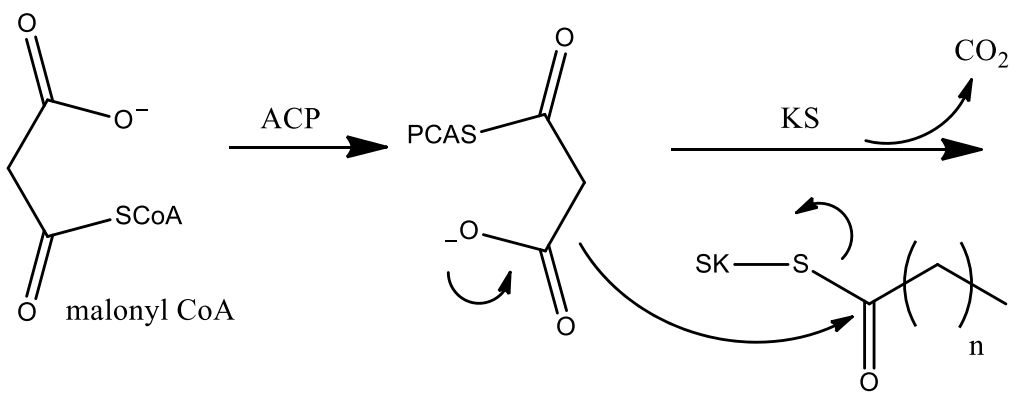<smiles></smiles>
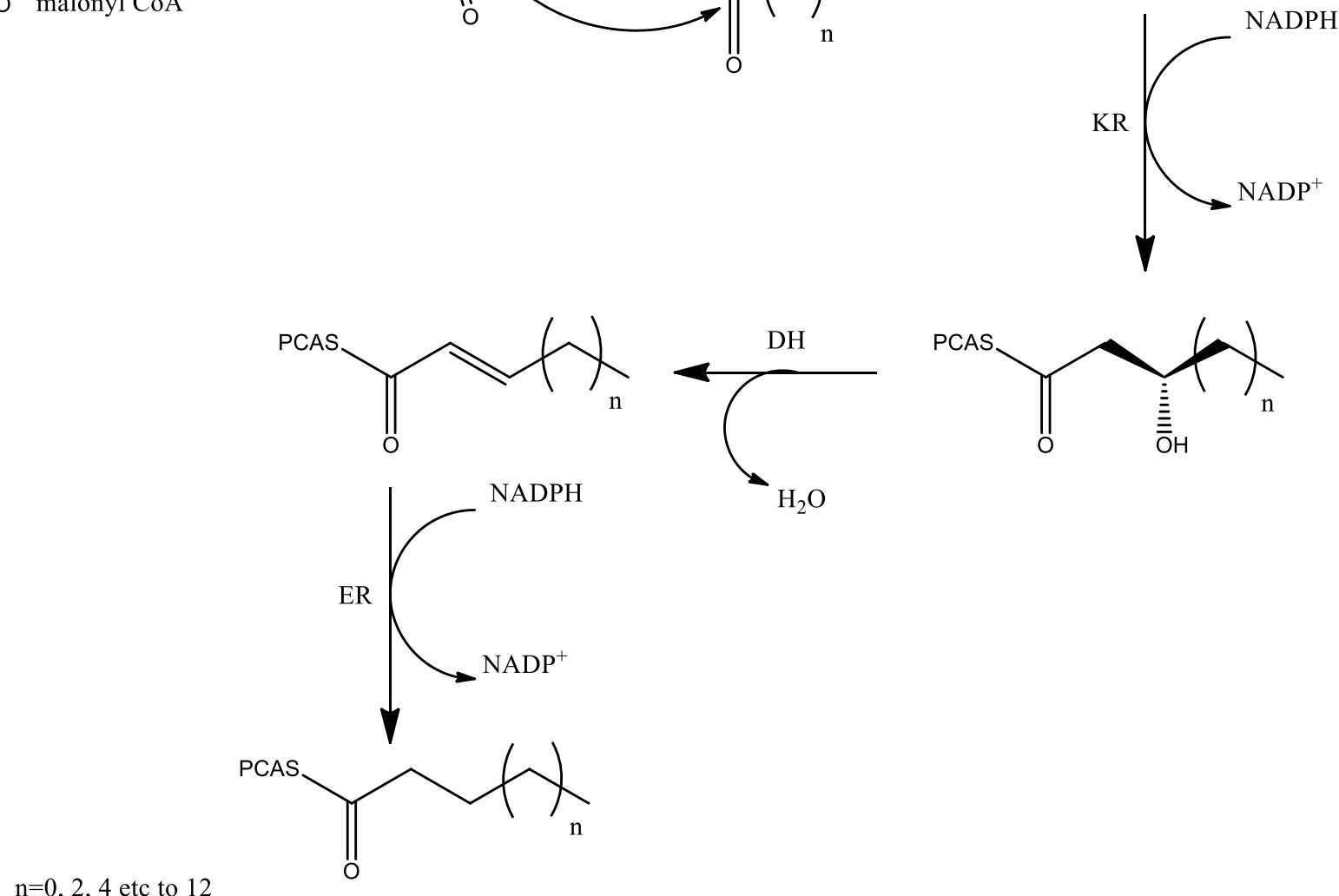

$\mathrm{n}=0,2,4$ etc to 12

Fig. 4. Biosynthesis of fatty esters from malonyl CoA (KS - $\beta$-keto synthase; DH - dehydratase; ER - enoyl reductase; KR - $\beta$-keto reductase; ACP - acyl career protein).

is a specific molecule, possessing lipophilic "tail" and hydrophilic "head" (Fig. 7).

However, recently, animal fats were mainly used for the production of soaps, the so-called "tallowates", mainly composed from saturated fatty acids and thus showing poor properties for body care applications. Also, when plant oils were used for the soap production in the recent years, there were mainly results of the final pressings (best pressings being reserved for the food industry), therefore also delivering mainly palmitates and stearates, i.e. saturated fatty acids.

Taking this into account, the perspectives for this specific application of insects' oil may be rather interesting and different from the rest of the cosmetic field, which is mainly seeking to avoid animal origin for their products. Indeed, the soaps are already mainly produced from animal origin, tallowates, and the quality of the insect oil is much better even comparing to the plant oils, as for now both the regulation and the social acceptance are preventing the insects' oils from the food industry.
Other, industrial, surfactants can also be made from the insects' oils, mainly the anionic and the zwiterionic ones (Fig. 8). Here the insect industry can beneficiate from the recent works aimed on the non-food valorization of some plant oils.

\subsection{Materials}

In this field as in the previously mentioned field of surfactants, the insects' oils can beneficiate from all the studies made in the recent years for the non-food oil applications. More particularly, the example of urethanes, was extensively studied.

Indeed, urethanes are crucial intermediates in the synthetic route to polyurethanes, a very widely used and versatile polymeric material. The main issue is, that to get to urethane, one needs to pass through isocyanates, an extremely unsafe chemical (Fig. 9).

Some studies have shown that another route was possible, namely the possibility to start with fatty acids, to get to the 


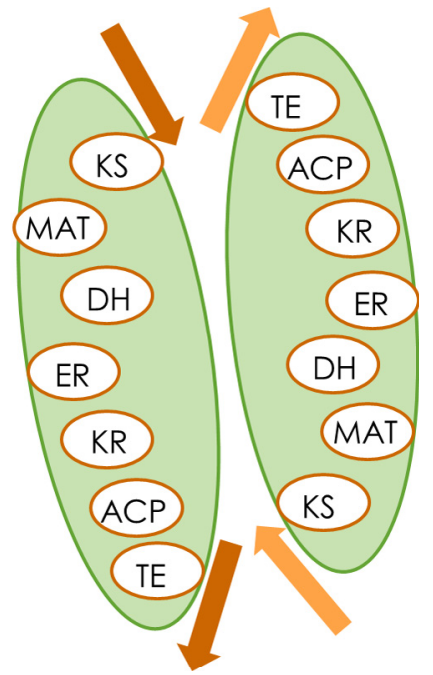

Fig. 5. Type I fatty acid synthase (KS - $\beta$-keto synthase; MAT malonyl acetate transferas; DH - dehydratase; ER - enoyl reductase; $\mathrm{KR}$ - $\beta$-keto reductase; ACP - acyl career protein; TE thioestease). epoxides, either by conserving the whole molecule or by breaking it at the double bond position (Fig. 10), and then converting those epoxides first to carbamate and then to urethane (Fig. 11). These synthetic pathways open the route to the so-called "non-isocyanate" polyurethanes (NIPU) (Carre et al., 2014).

The main reason why those findings are not yet applied in the industry relies on the price of the raw materials, i.e. plant oils, and their concurrence with the food industry. As already outlined here above, in the case of insects, the situation is completely different, as for regulation and social reasons insects' oils are not used for food and as the insects' oils are not the main, but the co-product of the insect industry.

\section{Outlook}

Even if the insect industry remains at its infancy, it is worthwhile to look at the valorization of its major co-product, the insects' oils, to consider the global economical and other sustainability of this field. After a deeper look on those product, their biosynthesis and composition, different applications can be foreseen.

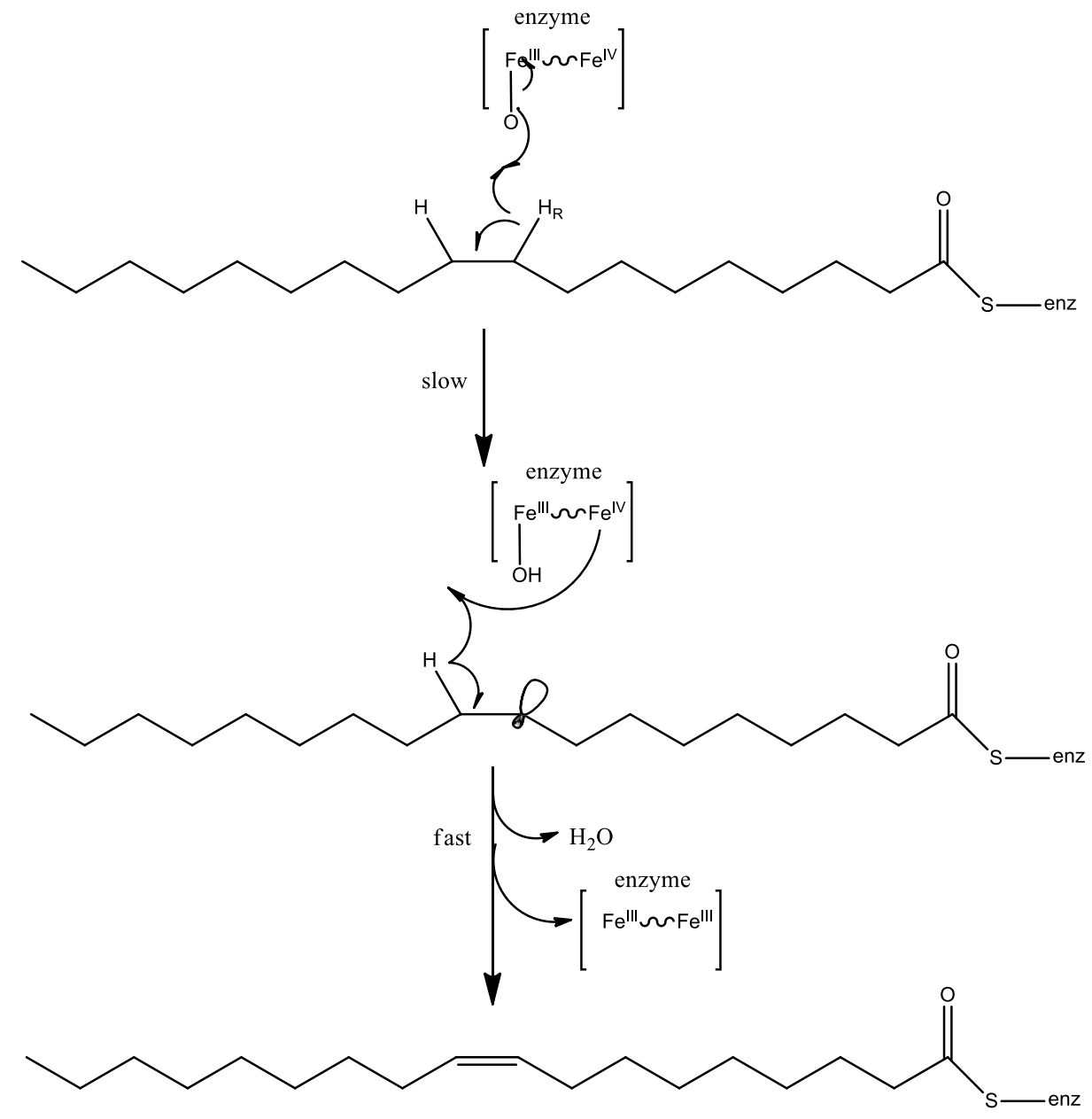

Fig. 6. Desaturation of fatty acids. 
Table 1. Fatty acid composition of different insect orders.

\begin{tabular}{|c|c|c|c|c|c|c|c|c|}
\hline Order & $14: 0$ & $14: 1$ & $16: 0$ & $16: 1$ & 18:0 & $18: 1$ & $18: 2$ & $18: 3$ \\
\hline Lepidoptera & 1 & 0 & 26 & 6 & 2 & 32 & 8 & 22 \\
\hline Orthoptera & 2 & 0 & 29 & 3 & 8 & 32 & 12 & 9 \\
\hline Diptera & 3 & 1 & 23 & 26 & 4 & 28 & 12 & 2 \\
\hline
\end{tabular}

Table 2. Comparison of average fatty acids' compositions of some oils (Boscou et al., 2006; Caruso et al., 2014; Jeon et al., 2016; Jokic et al., 2013; Popa et al., 2012).

\begin{tabular}{|c|c|c|c|c|c|c|c|c|c|}
\hline Fatty Acids & $\begin{array}{l}\text { T. molitor } \\
\text { oil }\end{array}$ & $\begin{array}{l}\text { H. illucens } \\
\text { oil }\end{array}$ & $\begin{array}{l}\text { Olive } \\
\text { oil }\end{array}$ & $\begin{array}{l}\text { Peanut } \\
\text { oil }\end{array}$ & $\begin{array}{l}\text { Canola } \\
\text { oil }\end{array}$ & $\begin{array}{l}\text { Sun flower } \\
\text { oil }\end{array}$ & Soya oil & Linseed oil & \\
\hline Myristic & $14: 0$ & 2,8 & 3 & 0 & 0.05 & 0 & 0 & 0 & 0 \\
\hline Stearic & $18: 0$ & 3.6 & 4 & 2.8 & 2.75 & 1.8 & 3.8 & 5 & 4.4 \\
\hline Oleic & $18: 1$ & 41.1 & 28 & 69 & 52 & 63 & 26.7 & 22 & 18.5 \\
\hline Linoleic & $18: 2$ & 29.7 & 12 & 12.3 & 27.5 & 20 & 61.2 & 53 & 17.3 \\
\hline Total UFA* & 72.3 & 69 & 82.3 & 91.6 & 91.6 & 88 & 80 & 89 & \\
\hline Total PUFA** & 31.2 & 20 & 13.3 & 27.65 & 28.6 & 61.3 & 58 & 70.5 & \\
\hline
\end{tabular}

${ }^{*}$ UFA: unsaturated fatty acids.

** PUFA: polyunsaturated fatty acids.

Table 3. Comparison of advantages and drawbacks of different sources of biodiesel (Schlagermann et al., 2012; Zheng et al., 2013).

\begin{tabular}{|c|c|c|c|c|c|}
\hline & Insect oil & Canola oil & Jatropha oil & Palm oil & Algae \\
\hline $\begin{array}{l}\text { Arable land / feedstock } \\
\text { concurrence }\end{array}$ & no & yes & no & yes & no \\
\hline Needed surfaces /density & (almost) none & $4-10$ plants $/ \mathrm{ft}^{2}$ & 1000 plants/ha & 143 plants/ha & $0,25 \mathrm{~kg} / \mathrm{m}^{3}$ \\
\hline Rapidity of growth & $2-3$ months & 6-9 months & $\begin{array}{l}5 \text { years to achieve } 5-7 \mathrm{t} / \mathrm{ha} \\
\text { ( } 250 \mathrm{~kg} \text { in practice) }\end{array}$ & $\begin{array}{l}\text { cycles of } 25 \text { years } \\
\text { ( } 4 \text { years to start } \\
\text { harvesting) }\end{array}$ & 10 days \\
\hline
\end{tabular}

Table 4. Comparison of some properties of biodiesels (adapted from Zheng et al., 2013).

\begin{tabular}{llll}
\hline Properties & EN 14214 & $\begin{array}{l}\text { T. molitor } \\
\text { biodiesel }\end{array}$ & $\begin{array}{l}\text { H. illucens } \\
\text { biodiesel }\end{array}$ \\
\hline Density $\left(\mathrm{kg} / \mathrm{m}^{3}\right)$ & $860-900$ & 860 & 872 \\
biodiesel \\
Flash point $\left({ }^{\circ} \mathrm{C}\right)$
\end{tabular}




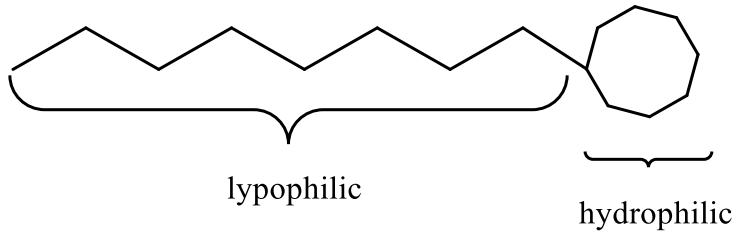

Fig. 7. General scheme of surfactant molecules.
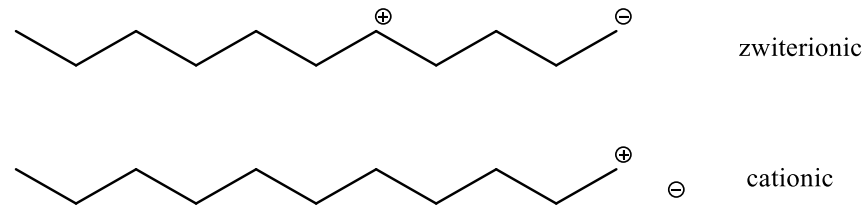

Fig. 8. Anionic and zwiterionic "tails" of surfactants.<smiles>O=C(Cl)Cl</smiles>

phosgene

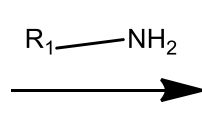<smiles>[R]N=C=O</smiles>

isocyanate<smiles>[R]NC(=O)O[R]</smiles>

urethane

Fig. 9. Urethane synthesis.
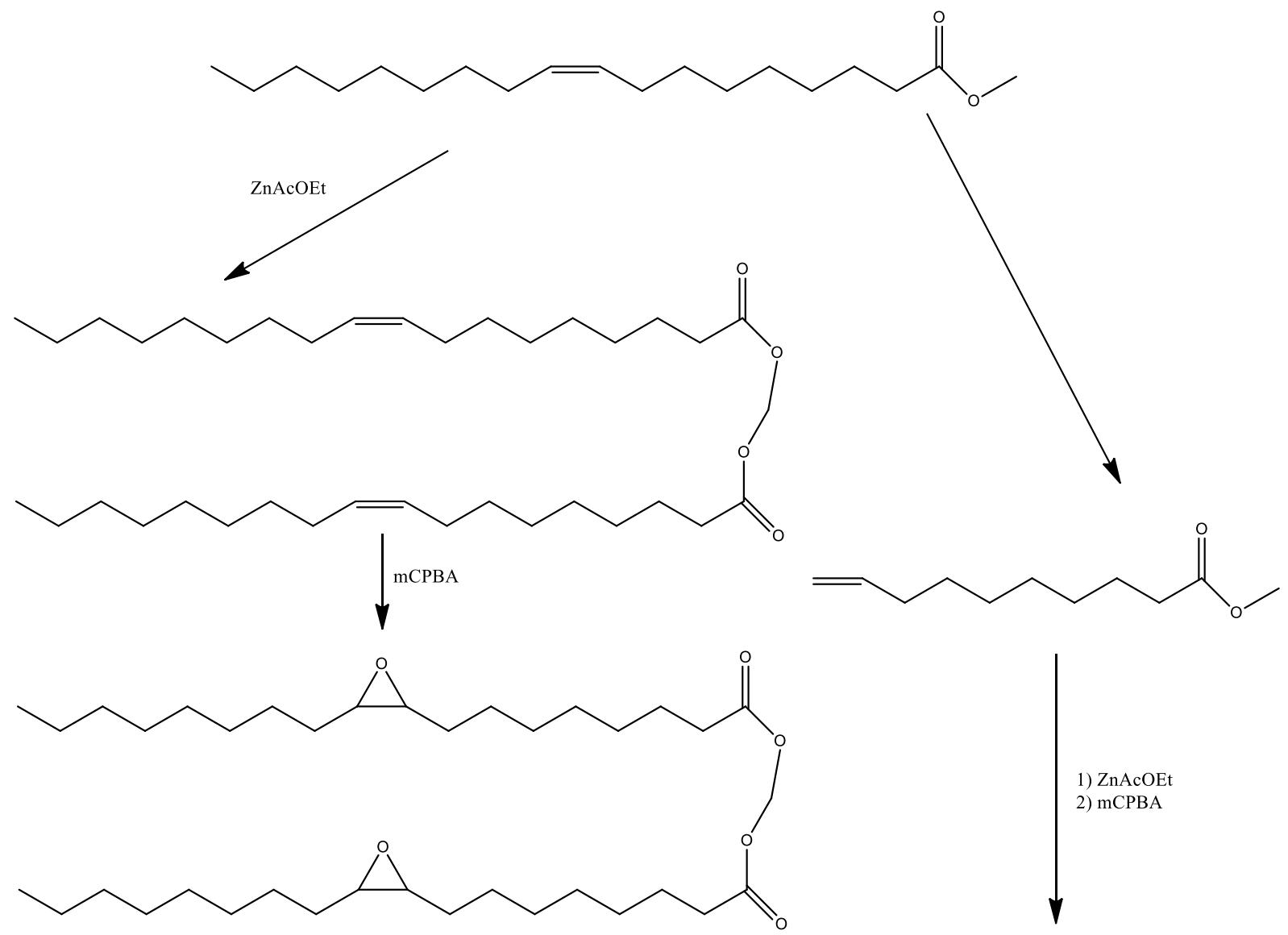<smiles>CCCCCCCCCC1CO1</smiles><smiles>COC(=O)CCCCCCCC1CO1</smiles>

Fig. 10. Production of epoxides starting with fatty acids. 


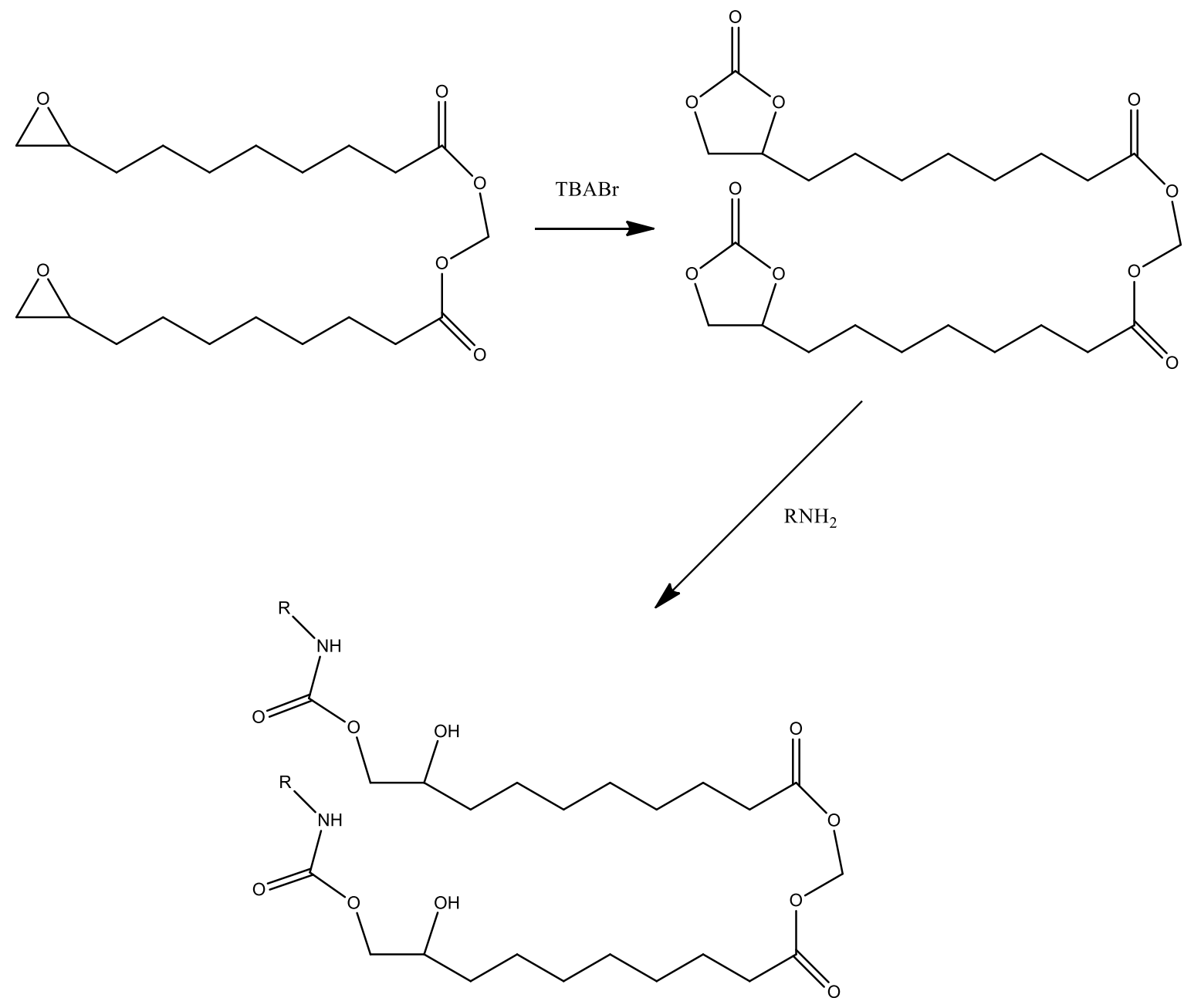

Fig. 11. Production of urethanes from epoxides.

Among the investigated applications, the feed and food applications seem very interesting according to the fatty acid and overall UFA/PUFA ratio of the oils from the insects. However, food applications require the specific regulation, Novel Food in Europe, and social acceptance. Other promising applications were thus underlined, such as soaps and other surfactants as well as materials applications, namely for the production of non-isocyanate polyurethanes (NIPU). Also the biodiesel application can be foreseen for these oils, as their performance in many points is higher than what was observed up to now for plants' oils.

Finally, lots remain to be done for the better understanding and comprehension of the specificity of the difference of the oils among the insect biodiversity, such as specific compounds, e.g. specific sterols, namely tocopherols, cholesterols etc. for some niche market applications.

\section{References}

Berezina N, Hubert A, Berro F, Levon JG, et al. 2016a. Chitin, hydrolysate and production of at least one desired product from insects by means of enzymatic hydrolysis, comprising a combination of steps performed prior to the enzymatic hydrolysis, patent WO2016108035.
Berezina N, Hubert A, Berro F, Levon JG, et al. 2016b. Chitin, hydrolysate and method for the production of one or more desired products by means of enzymatic hydrolysis, including pretreatment with an oxidising agent, patent WO2016108034.

Berezina N, Hubert A, Berro F, Levon JG, et al. 2016c. Chitin, hydrolysate and method for the production of one or more desired products from insects by means of enzymatic hydrolysis, patent WO2016108033.

Boscou D, Blekas G, Tsimidou M. 2006. Olive oil composition. In: Chemistry, properties, health effects. Rome: AOCS Press, pp. 41-72.

Carre C, Bonnet L, Averous L. 2014. Original biobased nonisocyanate polyurethanes: solvent- and catalyst-free synthesis, thermal properties and rheological behaviour. RSC Adv 4: 54018-54025.

Caruso D, Devis E, Subamia IW, Talamond P, Baras E. 2014. Technical handbook of domestication and production of diptera BSF. IRD ED., IPB Press.

Jeon YH, Son YJ, Kim SH, Yun EY, Kang HJ, Hwang IK. 2016. Physicochemical properties and oxidative stabilities of mealworm (Tenebrio molitor) oils under different roasting conditions. Food Sci Biotechnol 25: 105-110.

Jokic S, Sudar R, Svilovic S, Vidovic S, Bilic M, Velic D, et al. 2013. Fatty acid composition of oil obtained from soybeans by extraction with supercritical carbon dioxide. Czech J Food Sci 31: 116-125. 
Kerkut GA, Gilbert LI. 1985. Comprehensive insect physiology, biochemistry and pharmacology. Bogor: Pergamon press, vol. 10.

Mariod AA. 2005. Investigations on the oxidative stability of some unconventional Sudanese oils, traditionally used in human nutrition. $\mathrm{PhD}$ thesis.

Morgan DE. 2010. Biosynthesis in insects. Adv. Ed. RSC Publishing.

Popa V-M., Gruia A, Raba D-N., Dumbrava D, Moldovan C, Bordean D, et al. 2012. Fatty acids composition and oil characteristics of linseed from Romania. J Agroalm Process Technol 18: 136-140.
Schlagermann P, Gottlicher G, Dillschneider R, Rosello-Sastre R, Posten, C. 2012. Composition of algal oil and its potential as biofuel. J Combustion 1-12.

Van Huis A, van Itterbeeck J, Klunder H, Mertens E, Halloran A., Muir G, et al. 2013. Edible insects: future prospects for food and feed security. FAO Forestry paper.

Zheng L, Hou Y, Li W, Yang S, Li Q, Yu Z. 2013. Exploring the potential of grease from yellow mealworm beetle (Tenebrio molitor) as a novel biodiesel feedstock. Appl Energy 101: 618-621.

Cite this article as: Berezina N. 2017. Insects: novel source of lipids for a fan of applications. OCL 24(4): D402. 